\title{
FUTURE SUSTAINABLE CONCENTRATING SOLAR POWER TECHNOLOGIES: A REVIEW
}

\author{
A.M.K. El-Ghonemy \\ High Institute of Engineering and Textile Technology, Egypt \\ Email:amghonemy@yahoo.com
}

\begin{abstract}
Concentrating solar thermal power is a renewable energy (RE) technology which converts solar irradiation into heat energy at high temperature and in a successive step into electricity. The core part is a number of mirrors which reflects direct normal irradiance (DNI) to a focal line or point, called a receiver. Temperatures up to $1000{ }^{\circ} \mathrm{C}$ can be achieved. These plants make use of conventional steam cycles, in which hybrid operation with fossil fuels is applicable. The key advantage of CSP in comparison to other RE technologies is that the need for fossil fuel can be reduced by over sizing the solar collector field and storing the extra heat. This paper is directed to provide a comprehensive review of CSP technologies that are sustainable for applications in MENA region. More focus was directed to the performance data with emphasis on technologies, economics and costs. A comparative study between different CSP technologies as well as performance and economics has been done. Finally, some general guidelines are given for the selection CSP systems and the parameters that are needed to be considered for decision makers.

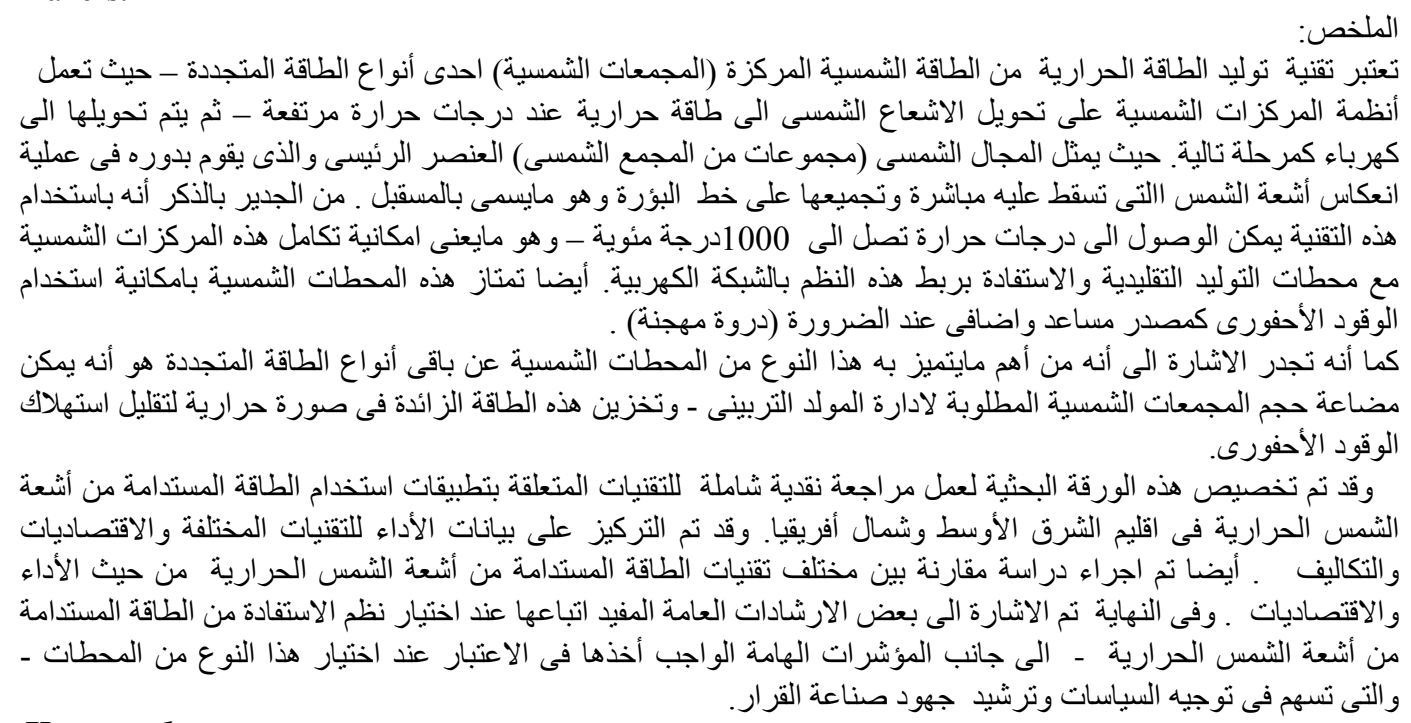

Keywords: Concentrated Solar Power (CSP) Plant, Concentrated Solar Collectors (CSCs), Power Generation.

\section{Introduction}

\subsection{Principle of concentrating solar power (CSP)}

The main element is a field of large mirrors reflecting the incident sun rays onto a small receiver element, thus concentrating the solar radiation intensity by 80 to several 100 times and producing high temperature heat at several 100 to over $1000{ }^{\circ} \mathrm{C}$. This heat can be either used directly in a thermal power cycle (based on steam turbines, gas turbines or
Stirling engines), or stored (in molten salt, concrete or phase-change material) to be delivered later to the power cycle for night-time operation [1].

The principle of operation of a concentrating solar power (CSP) plant is drafted in Figures (1), showing the different options for combined generation of heat and power.

CSP plants can be designed from $5 \mathrm{MW}$ up to several 100 MW of capacity [1]. 


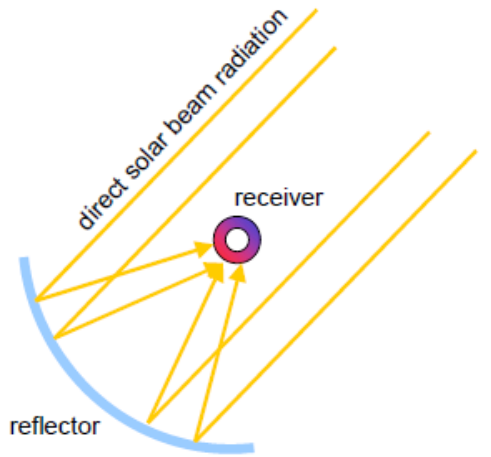

Figure (1-a): principle of a concentrated Solar collector [1].

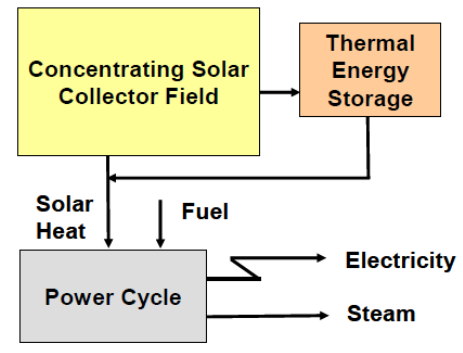

Figure (1-b): A concentrating solar thermal power station for co-generation of electricity and process steam

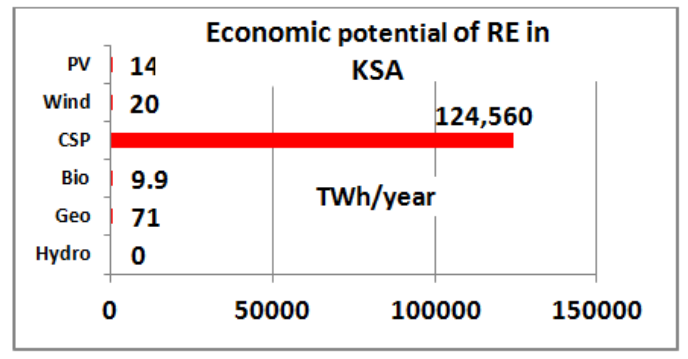

Figure (2): Economical potential for different $R E$

\subsection{Why MENA Regions}

All Middle East and North Africa (MENA) regions have an outstanding potential for solar energy.
Growth of population and economy, increasing urbanization and industrialization, against the limited natural resources of potable water and energy in MENA are leading to serious deficits. Generally, all CSP technologies can be used for generating electricity and heat. However, the more focus is on CSP for Electricity production, HVAC and the production of safe drinking water because these constitute major needs of developing countries (MENA. Consequently, the bulk of this new CSP capacity is expected to be seen in the MENA region, where it has abundant solar radiation (fig.3), cheap land and high electricity demand) [1]. The economic potential of renewable energy (RE) in Saudi Arabia is illustrated in figure (2) [11]. From this figure, it is clear that CSP has the highest economic potential.

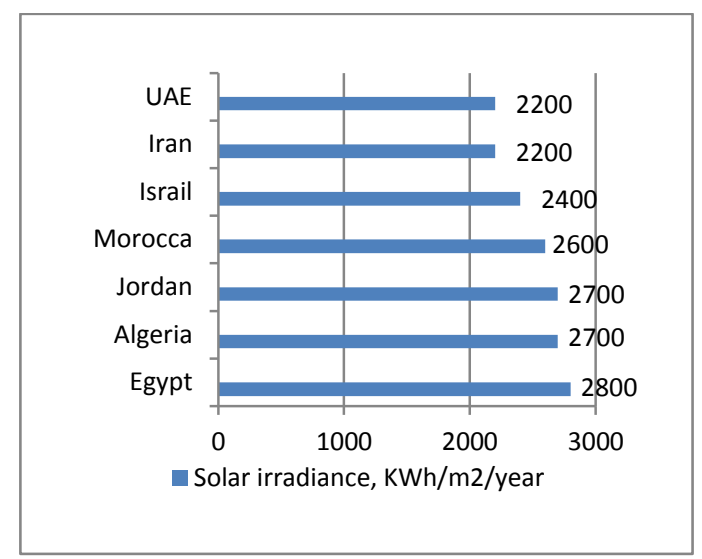

Fig (3): Solar irradiance for different countries, $\mathrm{kWh} / \mathrm{m}^{2} /$ year [14-16].

\subsection{CSP Market for MENA Region [15-16]}

The CSP global capacity is expected to reach 13 GW by year 2015, indicating that solar CSP is moving to the forefront of renewable energy technologies. The bulk of this new capacity is expected to be seen in the MENA region, where it has abundant solar radiation, cheap land and high electricity demand.

Table (1): Announced capacity for electricity from CSP[14-16].

\begin{tabular}{|c|c|c|c|c|}
\hline location & $\begin{array}{l}\text { Solar irradiance, } \\
\mathrm{kWh} / \mathrm{m}^{2} / \text { year }\end{array}$ & Planned CSP capacity(MW) & $\begin{array}{l}\text { Economic potential, } \\
\text { TWh }\end{array}$ & $\begin{array}{l}\text { Technical potential, } \\
\text { TWh }\end{array}$ \\
\hline Algeria & 2700 & 255 & 168972 & 169440 \\
\hline Egypt & 2800 & 30 & 73656 & 73656 \\
\hline Morocco & 2600 & 30 & 20146 & 20151 \\
\hline UAE & 2200 & 100 & 1988 & 2078 \\
\hline Jordan & 2700 & 30 & 6429 & 6434 \\
\hline Iran & 2200 & 70 & 20000 & $>20000$ \\
\hline Israel & 2400 & 100 & 318 & 318 \\
\hline
\end{tabular}




\subsection{Objectives}

This paper is directed to provide a comprehensive review of CSP technologies that are sustainable for applications in MENA regions, where it has abundant solar radiation, cheap land and high electricity demand.. More focus is directed to the performance data with emphasis on technologies economics and costs.. A comparative study between different CSP technologies as well as performance and economics has been done. Finally, some general guidelines are given for the selection CSP systems and the parameters that are needed to be considered.

\section{Basics and Types of CSP [1-18]}

Four primary CSP designs are available in the market today:

- Parabolic troughs (PT),

- Linear-Fresnel systems (LF),

- The Stirling engine (SE), and

- Solar towers (ST).

In parabolic trough systems, each trough has its own receiver, while Fresnel reflectors are made of many thin, flat mirror strips to concentrate sunlight onto common tubes through which a working fluid is pumped.

A Stirling dish or dish engine system consists of a stand-alone parabolic reflector that concentrates light onto a receiver positioned at the reflector's focal point.

In tower systems, thousands of tracking mirrors in a field capture and reflect sunlight to a central receiver located at top of the tower. The different types of concentrating technologies are summarized in table (2).

Recently, more focus has been given to the parabolic trough (PT) concentrated solar thermal system (PT-CST). This technology fits well with the special needs of developing countries as a ready source of energy for water desalination and HVAC applications.

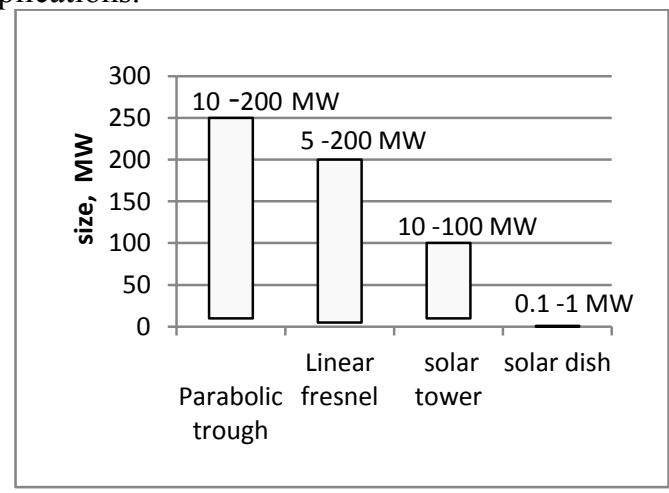

Fig.(4a):Capacity figures for different CSP technologies

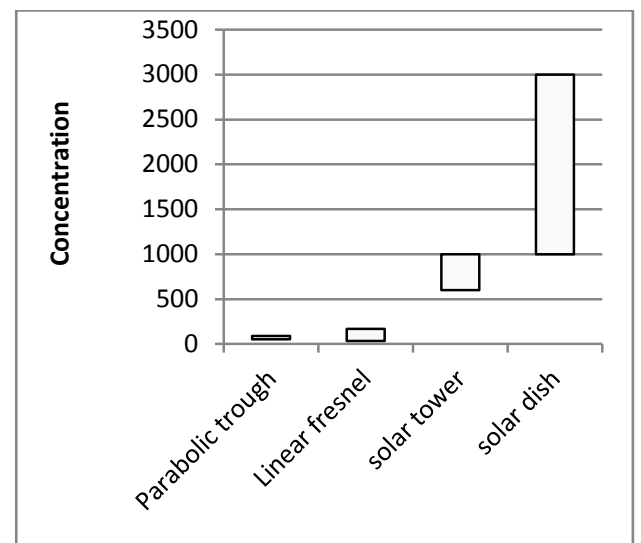

Fig.(4b):Concentration factor for different CSP technologies.

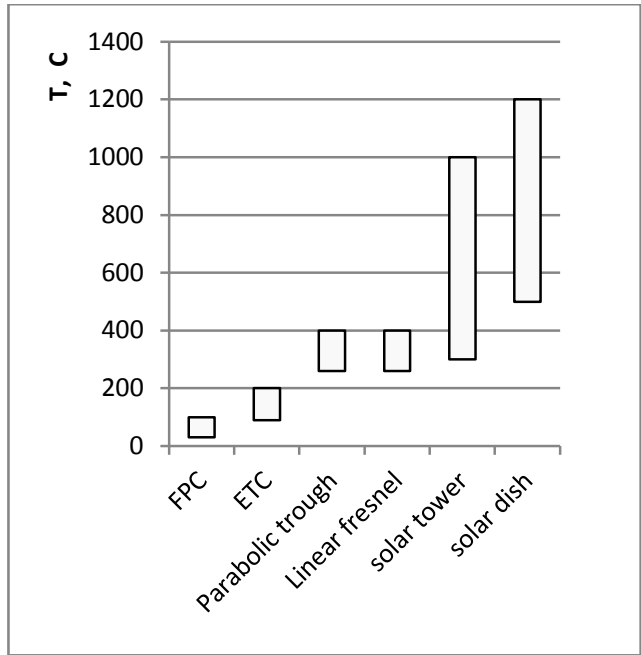

Fig.(4c):Achievable Temperatures for different CSP technologies $(F P C=$ Flat plate collector, ETC = Evacuated tube collector).

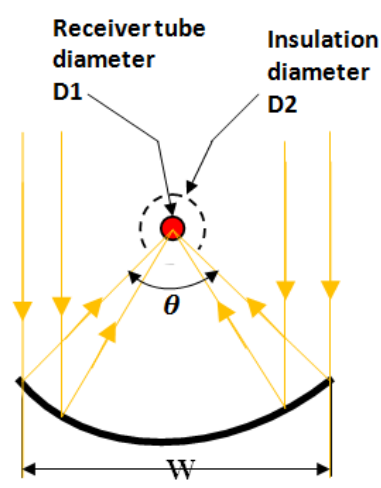

Figure (5): Back reflecting parabolic trough [4]. 
Table (2). Concentrating solar technologies [2,4].

\begin{tabular}{|c|c|c|c|c|}
\hline \multicolumn{2}{|c|}{ Optical method } & \multirow{2}{*}{$\begin{array}{l}\text { focus } \\
\text { line }\end{array}$} & \multirow{2}{*}{$\frac{\text { Temperature }\left({ }^{0} \mathbf{C}\right)}{300-550}$} & \multirow{2}{*}{$\begin{array}{l}\text { Heat transport to boiler } \\
\text { Oil, liquid salt, water+steam }\end{array}$} \\
\hline 1 & Parabolic trough mirror & & & \\
\hline 2 & Linear Fresnel mirror a & line & $250-500$ & Water+steam \\
\hline 3 & Linear Fresnel lens b & line & $250-400$ & Water+steam \\
\hline 4 & Solar tower with field of heliostats & point & $300-1000$ & Air, liquid salt, water+steam, gas turbine \\
\hline 5 & Solar dish & point & $400-1500$ & Stirling engine \\
\hline 6 & Fresnel lens & point & $400-1200$ & Micro turbine \\
\hline
\end{tabular}

\section{Solar Collectors[4,5,19-23]}

Focusing or Concentrating, collectors intercept direct solar radiation over a large area and focus it onto a small absorber area, see figure (5). These collectors can provide high temperatures more than flat-plate collectors.

However, diffused solar radiation cannot be focused onto the absorber. Most concentrating collectors require mechanical equipment in order to orients the collectors toward the sun and keeps the absorber at the point of focus. Therefore, there are four basic types of concentrating collectors:

- Stationary concentrating collectors

- Parabolic trough, figure (6).

- Power tower, figure(7)

- Parabolic dish, figure(8)

Typical performance parameters of various solar collectors are listed in tables(3).

Table (3). Typical concentration range and temperatures of various solar collectors [5, 19-23].

\begin{tabular}{|c|c|c|c|c|}
\hline Technology & $\mathbf{T},{ }^{\circ} \mathbf{C}$ & $\begin{array}{l}\text { Concentration } \\
\text { ratio }\end{array}$ & tracking & Max. conversion Efficiency, \%(Carnot) \\
\hline Flat plate collector & $30-100$ & 1 & - & $21 \%$ \\
\hline Evacuated tube collector & $90-200$ & 1 & $-\cdot$ & $38 \%$ \\
\hline Solar Pond & $70-90$ & 1 & -... & $19 \%$ \\
\hline Solar chimney & $20-80$ & 1 & $-\quad \ldots \ldots+\ldots \ldots$ & $17 \%$ \\
\hline Fresnel reflector & $260-400$ & $8-80$ & one-axis & $56 \%$ \\
\hline Parabolic trough & $260-400$ & $8-80$ & one-axis & $56 \%$ \\
\hline $\begin{array}{l}\text { Heliostat field+ central } \\
\text { receiver }\end{array}$ & $500-800$ & $600-1000$ & Two-axis & $73 \%$ \\
\hline Dish concentrator & $500-1200$ & $800-8000$ & Two-axis & $80 \%$ \\
\hline
\end{tabular}

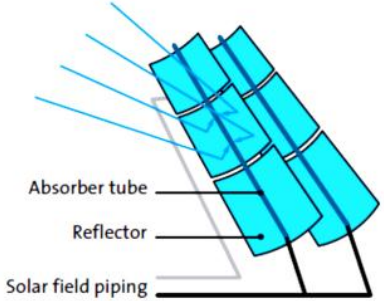

Figure (6). Schematic of PTC [16].

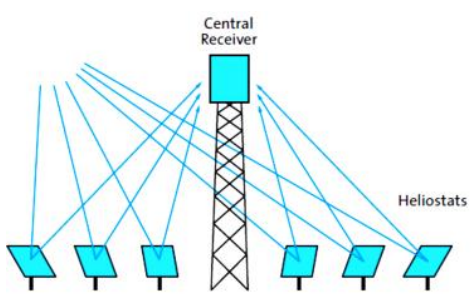

Figure (7). Schematic of solar tower [16].

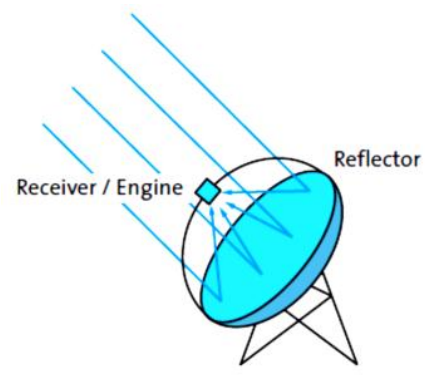

Figure (8).Schematic of solar dish [16].

\section{Main Components of CSP Systems}

Some of the components like the metal structure, the tracking system, controllers and other accessories, which make up to $60 \%$ of the direct solar field costs, are standard components and can be ordered from several countries and in different forms. However, reflectors and the absorber tube are special components and have to be produced specifically for the parabolic trough solar field. Main components of 
CSP system are listed below, (figure (9)):

1 Solar field collectors

2 Absorber/receiver

3 Heat transfer medium

4 Tracking system (single or double axis)

5 Balance of System

6 In case of power generation, the following components are included:

7 Steam turbine

8 Generator

a. Reflectors (concentrators)

The concentrators consist of a heat formed glass cake. Glass, which is used in solar applications, must have very low iron content for getting a transmissivity in the solar spectrum of about $91 \%$. The iron content of a so-called "White Glass" is about $0.015 \%$ compared to normal glass with an iron content of around $0.13 \%$. The binding of the reflectors is done under heat conditions. Several safety layer coatings are added, giving additional protection for the mirror. Finally the contour accuracy is tested using a laser beam.

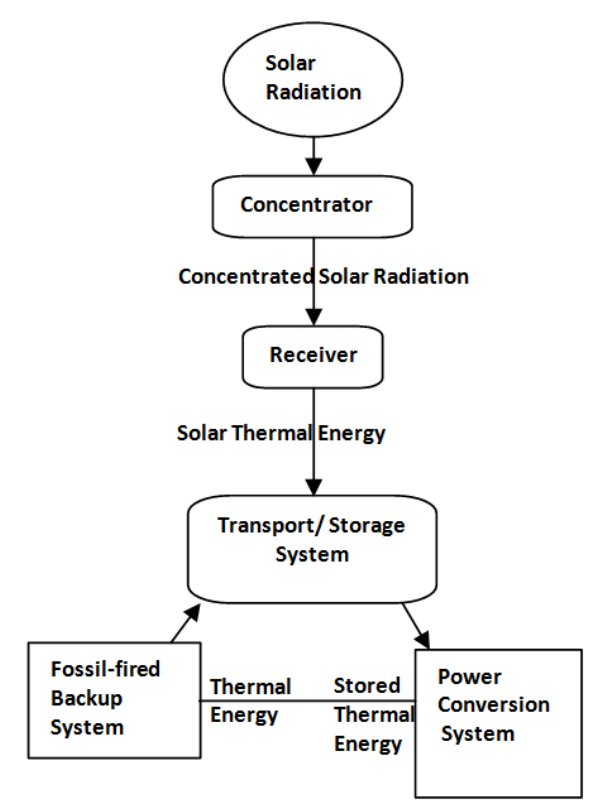

Figure (9).Main components of CSP system

\section{b. Absorber}

The absorber pipe consists of a stainless steel tube with a length of 4 meters and a thickness of $70 \mathrm{~mm}$. A glass pipe surrounds the tube (see figure 10) to allow evacuating of the area between the absorber tube and the glass pipe in order to minimize convection and conduction heat losses.

\section{c. Receiver}

The design of cylindrical cavity receivers is based on the concept of capturing the radiation in an insulated enclosure with an aperture that allows the inlet of the concentrated radiation beam (Figure 11). The working fluid flows axially in the annulus and extracts the energy from the cavity walls. The concentrated radiation focus is located at the cavity entrance. The interior of the cavity is painted with a black coating. No special coatings are required because the emittance of this coating is not critical for thermal losses.

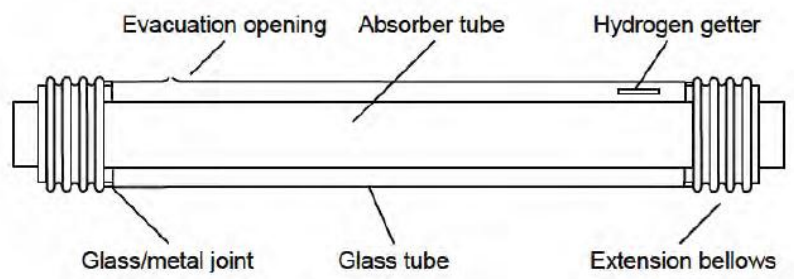

Figure (10).Absorber tube of a parabolic trough collector [66].

The vacuum also serves to protect the highly sensitive coating. Nowadays, such selective coatings remain stable in temperatures of $450^{\circ} \mathrm{C}$ up to $500^{\circ} \mathrm{C}$. The average solar absorptivity is currently above $95 \%$, an operational temperature is about $400^{\circ} \mathrm{C}$, and the emissivity is below $14 \%$. This leads to an optical efficiency of about $80 \%$ for incident perpendicular solar radiation. Furthermore the hydrogen getter (see figure 10) absorbs the hydrogen, which is getting through the glass pipe and the stainless steel pipe by diffusion. A membrane is used to pump the hydrogen out of the vacuum. Finally, glass/metal joints are used to compensate the thermal expansion of the pipe, and the connection between the glass pipe and the metal structure.

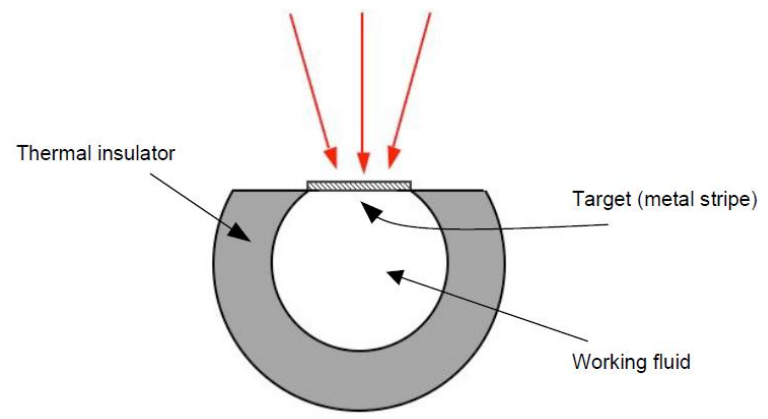

Figure (11).Cross section of tubular receiver [66]. 


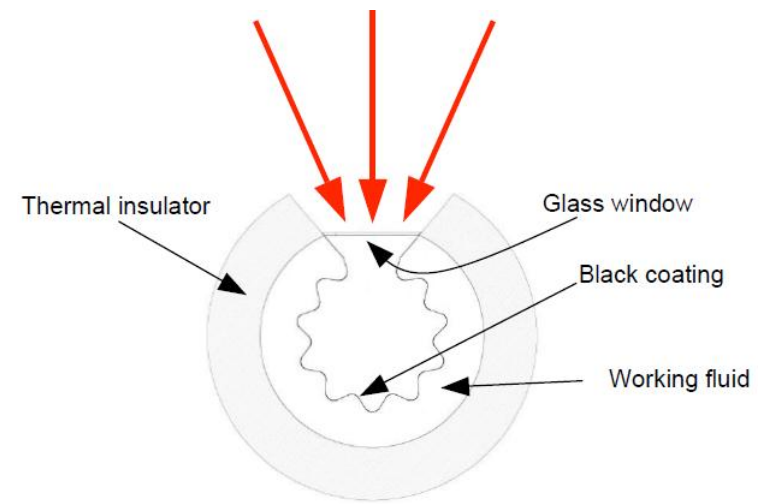

Figure (12).Cross section of cylindrical cavity receiver [66]

\section{Examples of Specific CSP Power Plants}

Examples of specific large solar thermal projects that are currently under construction or in advanced stage are given below:

- Algeria: $140 \quad-150 \quad \mathrm{MW}$, Integrated solar combined cycle (ISCC) plant with $25 \mathrm{MW}$ solar capacity (trough)

- Egypt: $150 \mathrm{MW}$ ISCC plant with $30 \mathrm{MW}$ solar capacity (trough)

- Greece: $50 \mathrm{MW}$ solar capacity using steam cycle (trough)
- India: $140 \mathrm{MW}$ ISCC plant with $30 \mathrm{MW}$ solar capacity (trough)

- Italy: $40 \mathrm{MW}$ solar capacity integrated into existing combined cycle plant (trough)

- Mexico: $291 \mathrm{MW}$ ISCC plant with $30 \mathrm{MW}$ solar capacity (trough)

- Morocco: 220 MW ISCC plant with 30 MW solar capacity (trough)

- Spain: over $500 \mathrm{MW}$ solar capacity using steam cycle $(4 \times 10-20 \mathrm{MW}$ solar tower and 12 x 50 MW parabolic trough)

- USA: $50 \mathrm{MW}$ solar capacity with parabolic trough in Nevada using steam cycle, preceded by a $1 \mathrm{MW}$ parabolic trough demonstration plant using ORC turbine in Arizona

- USA: 500 MW Solar Dish Park in California, preceded by a $1 \mathrm{MW}(40 \times 25 \mathrm{~kW})$ test and demo installation

\section{CSP Current Performance [29-34]}

The current performance of the four CSP technology families is summarized in Table (4). PT plants are in use of commercial application. ST plants are currently making the transition to commercial application, and linear Fresnel and parabolic dishes are at the demonstration stage, and have not yet reached large-scale commercial application.

Table (4). Current performance of CSP technology families.

\begin{tabular}{|c|c|c|c|}
\hline CSP technology & $\begin{array}{l}\text { Peak solar to electricity } \\
\text { conversion efficiency }(\%)\end{array}$ & $\begin{array}{l}\text { Annual solar-to electricity } \\
\text { efficiency (\%) }\end{array}$ & $\begin{array}{l}\text { Water consumption, for wet/dry } \\
\text { cooling }\left(\mathrm{m}^{3} / \mathrm{MWh}\right)\end{array}$ \\
\hline Parabolic troughs $(\mathrm{PT})$ & $23-27$ & $15-16$ & $3-4 / 0.2$ \\
\hline Linear Fresnel (LF) systems & $18-22$ & $8-10$ & $3-4 / 0.2$ \\
\hline Solar Towers (ST) & $20-27$ & $15-17$ & $3-4 / 0.2$ \\
\hline Parabolic dishes & $20-30$ & $20-25$ & $<0.1$ \\
\hline
\end{tabular}

Performance data for PT, LF and ST are obtained from commercial plants based on a Rankine cycle and using synthetic oil or steam as HTF. Data for parabolic dishes are based on dish-Stirling systems.

7. Comparison of CSP Technologies [1-10]

A comparison of the key parameters of the four types of CSP technologies is summarized in tables (5).

Table (5). Key Performance data of various CSP technologies [3,6]

\begin{tabular}{|l|l|l|l|l|l|l|l|l|}
\hline & $\begin{array}{l}\text { Unit } \\
\text { Capacity } \\
\text { MW }\end{array}$ & Concentration & $\begin{array}{l}\text { Peak } \\
\text { Solar } \\
\text { Efficiency }\end{array}$ & $\begin{array}{l}\text { Annual } \\
\text { Solar } \\
\text { Efficiency }\end{array}$ & $\begin{array}{l}\text { Thermal } \\
\text { Cycle } \\
\text { Efficiency }\end{array}$ & $\begin{array}{l}\text { Land } \\
\text { Capacity } \\
\text { Factor (solar) }\end{array}$ & $\begin{array}{l}\text { Useneration } \\
\text { weighted) } \\
\mathbf{m}^{2} / \mathbf{M W h} / \mathbf{y}\end{array}$ \\
\hline $\begin{array}{l}\text { Trough } \\
\text { (10-200 }\end{array}$ & $70-80$ & $21 \%(\mathrm{~d})$ & $10-15 \%(\mathrm{~d})$ & $30-40 \% \mathrm{ST}$ & $24 \%(\mathrm{~d})$ & $6-8$ \\
\hline Fresnel & $10-200$ & $25-100$ & $20 \%(\mathrm{p})$ & $9-11 \%(\mathrm{p})$ & $30-40 \% \mathrm{ST}$ & $25-90 \%(\mathrm{p})$ & $4-6$ \\
\hline $\begin{array}{l}\text { Power } \\
\text { Tower }\end{array}$ & $10-150$ & $300-1000$ & $20 \%(\mathrm{~d})$ & $8-10 \%(\mathrm{~d})$ & $30-40 \% \mathrm{ST}$ & $25-90 \%(\mathrm{p})$ & $8-12$ \\
\hline $\begin{array}{l}\text { Dish- } \\
\text { Stirling }\end{array}$ & $0.01-0.4$ & $1000-3000$ & $29 \%(\mathrm{~d})$ & $16-18 \%(\mathrm{~d})$ & $30-40 \%$ & $25 \%(\mathrm{p})$ & $8-12$ \\
\hline
\end{tabular}

$(\mathrm{d})=$ demonstrated, $(\mathrm{p})$ = projected, ST: steam turbine, GT: Gas Turbine, CC: Combined Cycle. Solar efficiency $=$ net power generation $/$ incident beam radiation, Capacity factor $=$ solar operating hours per year $/ 8760$ hours per year. 


\section{CSP Applications for MENA Region [41-57]}

Electricity generation, HVAC, and the production of safe drinking water are the more focus on CSP applications, because these constitute the major needs in developing countries (MENA). The three major subsystems are shown in figure (13).

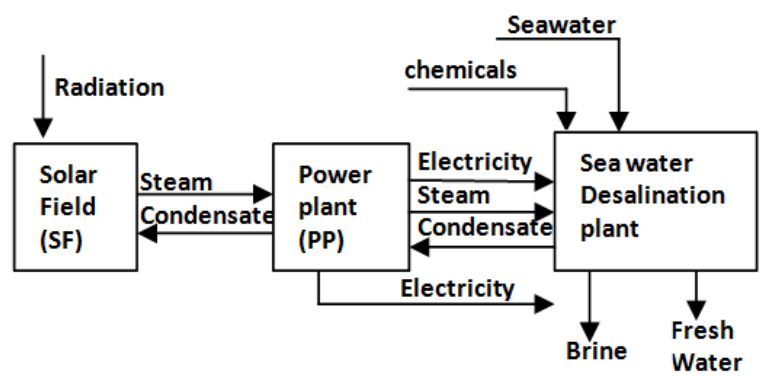

Figure (13). Block diagram of the solar thermal cogeneration system [31].

\subsection{CSP application in Water Desalination}

Three different options for a combination between CSP technologies and desalination were addressed in Figure (14):

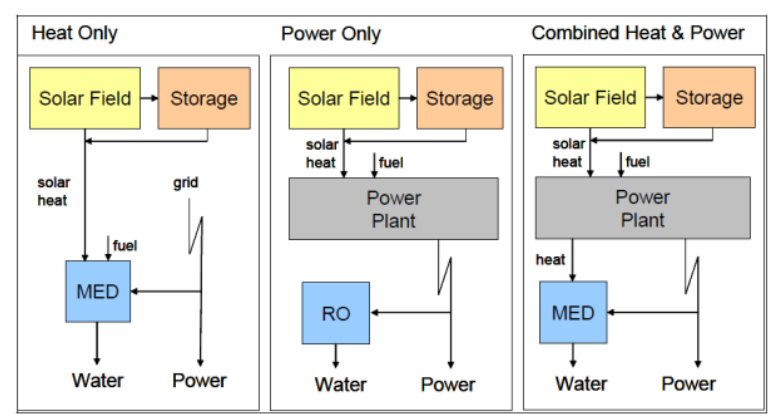

Figure (14). Different configurations for desalination by concentrated solar power [1,5-9](RO=reverse osmosis, MED=multi-effect desalination).

1. small-scale desalination plants directly powered by concentrating solar thermal collectors,

2. CSP plants providing electricity for reverse osmosis desalination (CSP/RO).

3. Combined generation of electricity and heat for thermal multi-effect desalination systems (CSP/MED).

Although Multi-Stage Flash (MSF) desalination is the common type in the MENA region, it has not been considered as viable future option for solar powered desalination. This is due to the higher temperature requirement of the MSF process compared to that of MED system.

Table (6). Overview on market available thermally driven cooling systems based on sorption technology [22].

\begin{tabular}{|c|c|c|c|c|c|c|c|c|}
\hline \multirow{2}{*}{$\begin{array}{l}\text { Type of system } \\
\text { Physical phase of } \\
\text { sorption material }\end{array}$} & \multicolumn{6}{|c|}{ Water chillers (closed thermodynamic cycles) } & \multicolumn{2}{|c|}{$\begin{array}{l}\text { Direct air treatment (open thermodynamic } \\
\text { cycles) }\end{array}$} \\
\hline & Liquid & Liquid & Liquid & Solid & Solid & Solid & Liquid & solid \\
\hline Sorption material & water & $\begin{array}{l}\text { Lithium } \\
\text { bromide }\end{array}$ & $\begin{array}{l}\text { Lithium } \\
\text { bromide }\end{array}$ & zeolite & Silica gel & $\begin{array}{l}\text { Lithium } \\
\text { chloride }\end{array}$ & Lithium-chloride & $\begin{array}{l}\text { Silica gel (or zeolite), } \\
\text { Cellulose matrix with } \\
\text { Lithium-chloride }\end{array}$ \\
\hline Refrigerant & Ammonia & Water & Water & Water & Water & Water & Water & Water \\
\hline Type of cycle & 1-effect & 1-effect & 2 -effect & 1-effect & 1 -effect & 1-effect & $\begin{array}{l}\text { Cooled sorption } \\
\text { process }\end{array}$ & Desiccant rotor \\
\hline EER thermal ratio & $0.5-0.75$ & $0.65-0.8$ & $1.1-1.4$ & $0.5-0.75$ & $0.5-0.75$ & $0.5-0.75$ & $0.7-1.1$ & $0.6-0.8$ \\
\hline $\begin{array}{l}\text { Driving temperature } \\
\text { range, }{ }^{\circ} \mathrm{C}\end{array}$ & $\begin{array}{l}70-100120- \\
180 \text { (SAT) }\end{array}$ & $70-100$ & $140-180$ & $65-90$ & $65-90$ & $65-90$ & $65-85$ & $60-80$ \\
\hline $\begin{array}{l}\text { Solar collector } \\
\text { technology }\end{array}$ & $\begin{array}{l}\text { FPC, ETC, } \\
\text { SAT }\end{array}$ & $\begin{array}{l}\text { FPC, } \\
\text { ETC }\end{array}$ & SAT & $\begin{array}{l}\text { FPC, } \\
\text { ETC }\end{array}$ & $\begin{array}{l}\text { FPC, } \\
\text { ETC }\end{array}$ & FPC, ETC & $\begin{array}{l}\text { FPC, ETC, } \\
\text { SAHC }\end{array}$ & $\begin{array}{l}\text { FPC, ETC, } \\
\text { SAHC }\end{array}$ \\
\hline
\end{tabular}

$\mathrm{FPC}=$ Flat plate collector, $\mathrm{ETC}=$ evacuated tube collector, $\mathrm{SAT}=$ single-axis tracking solar collector, $\mathrm{SAHC}=$ solar air heating collector.

\subsection{CSP application in Cooling Technology}

Generally the solar cooling system comprises of three sub-systems: the solar energy conversion system, refrigeration system, and the cooling load. The different ways to convert solar radiation into cooling and air conditioning are shown in Figure (15) and detailed in table (6). 


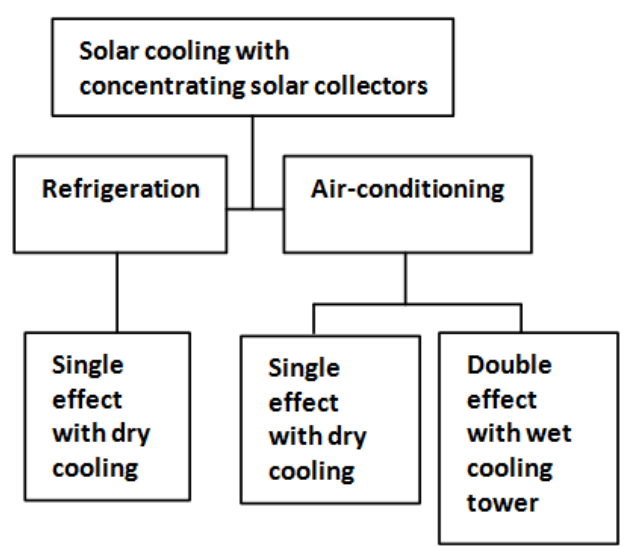

Figure (15).Categories of high temperature solar cooling systems utilizing concentrating solar collectors [35-40].
Solar energy can be converted into cooling using two main principles:

1 Electricity generated with photovoltaic modules can be converted into cooling using well-known refrigeration technologies that are mainly based on vapor compression cycles.

2 Heat generated with solar thermal collectors can be converted into cooling using thermally driven refrigeration or air-conditioning technologies. Most of these systems employ the physical phenomena of sorption in either an open or closed thermodynamic cycle. Other technologies, such as steam jet cycles or other cycles using a conversion of heat to mechanical energy and of mechanical energy to cooling are less significant.

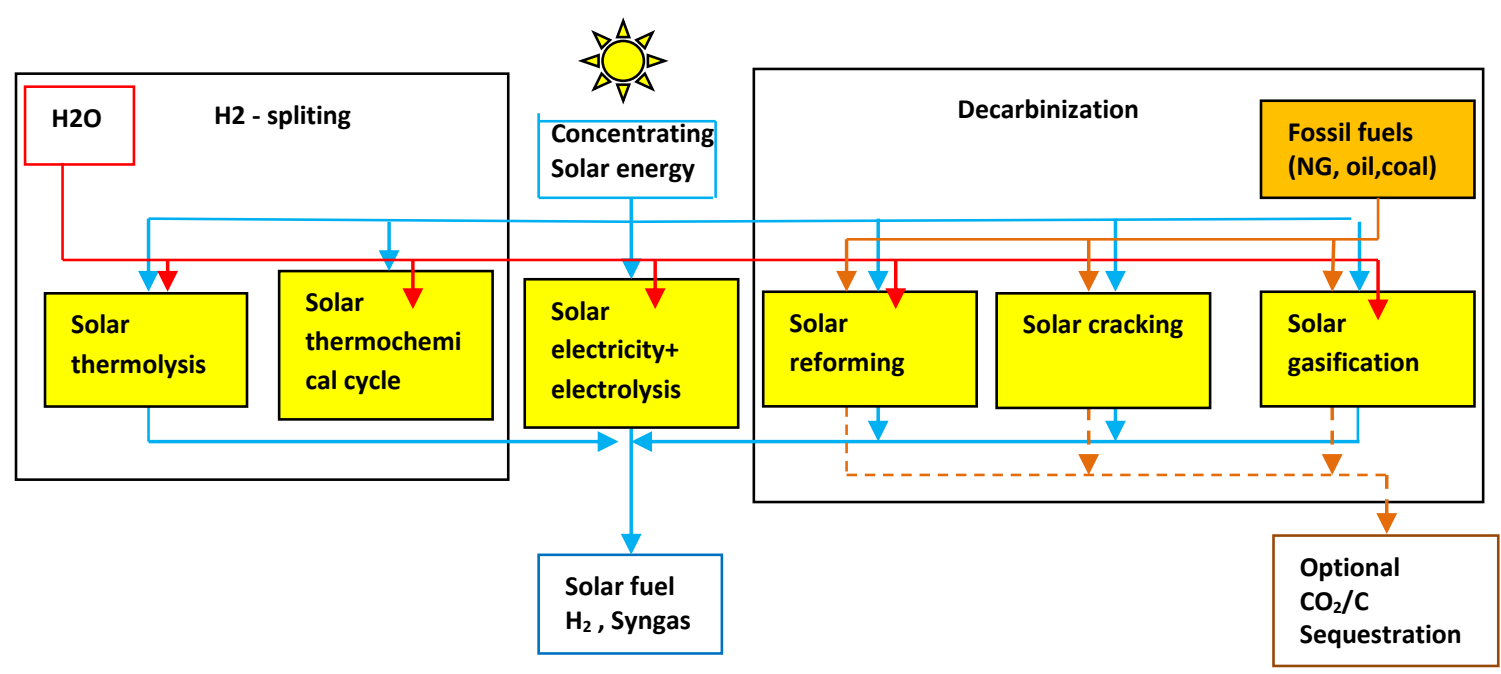

Figure (16). Different thermo-chemical methods for producing fuels using CSP [roadmap2010 [16]).

\subsection{CSP Application in H2 Technologies}

CST technologies also allow the production of Hydrogen (H2), which is considered as a form of storing solar energy. Then it can be distributed as a fuel to industry, households, etc. Production of solar hydrogen can be achieved via electrolysis of water using solar-generated electricity at an overall solar to hydrogen efficiency of about $10 \%$. Several options for $\mathrm{H} 2$ production using CSP are outlined in Figure (16).

\section{Pre-Selection of CSP Technologies [1]}

The aim of pre-selection here is to find the best suited CSP-technology that can be used with seawater desalination (with respect to performance and cost), see figure (17).

On the other hand, neither PT nor LF systems can be used to power gas turbines. In the high temperature range up to $1000{ }^{\circ} \mathrm{C}$ and more, central receivers are the only available option to provide solar heat for gas turbines and combined cycle systems. However, it is still uncertain and still leaves open questions with respect to cost, reliability and scalability for mass production at large scale.

Looking at Table (7) the LF beats the PT with synthetic oil as heat transfer medium in many items. However, the most important issues like experience, reliability and availability of TES, the linear Fresnel system is in an inferior position compared to the parabolic trough system. This fact is not compensated by the less cost of the solar field of the linear Fresnel system. 
Parabolic trough power plants represent about $88 \%$ of the worldwide installed CSP capacity and about $97.5 \%$ of all capacity which is currently under construction (CSP Today, 2011).

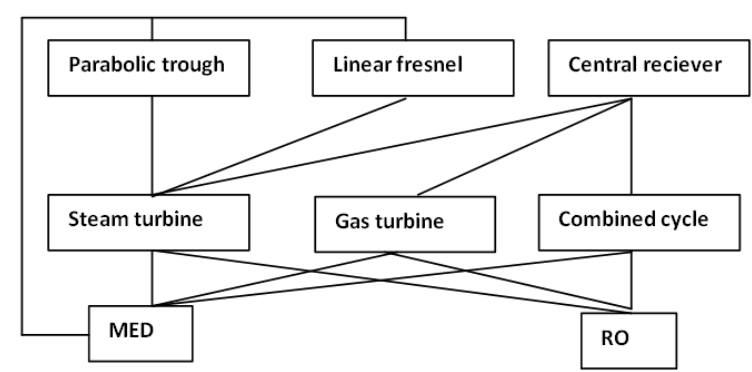

Figure (17): Options of large scale concentrating solar power and desalination systems [1].

Table (7). Characteristics of current concentrating solar power technologies (PCM: Phase Change Materials) [35-40].

\begin{tabular}{|c|c|c|c|c|c|c|}
\hline \multirow{2}{*}{$\begin{array}{l}\text { Concentration } \\
\text { Method } \\
\text { Technology }\end{array}$} & \multicolumn{3}{|c|}{ Line Concentrating Systems } & \multicolumn{3}{|c|}{ Point Concentrating Systems } \\
\hline & \multicolumn{2}{|c|}{ Parabolic Trough } & \multirow{2}{*}{$\begin{array}{l}\text { Linear Fresnel } \\
\text { Water/Steam } \\
\text { Superheated and } \\
\text { saturated Steam } \\
\text { Cycle }\end{array}$} & \multicolumn{2}{|c|}{ Central Receiver } & \multirow{2}{*}{$\begin{array}{l}\text { Parabolic Dish } \\
\text { Air }\end{array}$} \\
\hline $\begin{array}{l}\text { Heat } \quad \text { Transfer } \\
\text { Fluid }\end{array}$ & $\begin{array}{l}\text { Synthetic } \\
\text { Oil }\end{array}$ & $\begin{array}{l}\text { Water / } \\
\text { Steam }\end{array}$ & & $\begin{array}{l}\text { Water/Steam, } \\
\text { Air }\end{array}$ & Pressurized Air & \\
\hline Power Cycle & $\begin{array}{l}\text { Superheated } \\
\text { Steam } \\
\text { Cycle }\end{array}$ & $\begin{array}{l}\text { Superheated } \\
\text { Steam Cycle }\end{array}$ & $\begin{array}{l}\text { Superheated and } \\
\text { saturated Steam } \\
\text { Cycle }\end{array}$ & $\begin{array}{l}\text { Superheated } \\
\text { and saturated } \\
\text { Steam Cycle }\end{array}$ & $\begin{array}{l}\text { Gas Turbine and } \\
\text { Combined Cycle }\end{array}$ & Stirling Engine \\
\hline \multicolumn{7}{|c|}{ Crucial Criteria } \\
\hline $\begin{array}{l}\text { Typical Unit Size } \\
\text { (MW) }\end{array}$ & $10-250$ & $10-250$ & $5-200$ & $10-100$ & $5-100$ & $0.1-1$ \\
\hline State of the Art & commercial & experimental & $\begin{array}{l}\text { recently } \\
\text { commercial }\end{array}$ & $\begin{array}{l}\text { semi- } \\
\text { commercial }\end{array}$ & experimental & demonestrated \\
\hline $\begin{array}{l}\text { Cost of Solar } \\
\text { Field }\left(€ / \mathrm{m}^{2}\right)\end{array}$ & $300-350$ & n. a. & $200-250$ & $300-400$ & $300-400$ & n.a \\
\hline $\begin{array}{l}\text { Investment Costs } \\
(€ / \mathrm{kW}) \text { for } \\
\mathrm{SM} 1 \text { - SM2 }\end{array}$ & $\begin{array}{l}3,500- \\
6,500\end{array}$ & n. a. & $2,500-4,500$ & $4,000-6,000$ & n.a. & $\begin{array}{l}6,000-10,000 \text { (only } \\
\text { SM1) }\end{array}$ \\
\hline
\end{tabular}

\section{Solar Tracking [3, 58-59]}

The concentrating collectors can be operated in three modes:

a- Fixed orientation mode.

At solar noon, the range of solar elevations during the year is $\pm 23.45^{\circ}$. Thus, a collector with fixed orientation must have an acceptance aperture halfangle of at least $23.45^{\circ}$.

For continuously tracking system, the acceptance aperture needs only to be large enough to include the solar disc; plus errors on mirrors or lens construction and errors in collector steerage orientation. This easily allows concentration ratios in the range of 5-15 and intermediate temperatures are also achievable.

b- Continuous tracking mode.

c- Periodic seasonal adjustment mode,

For periodic adjustment or fixed orientation, the concentrators must be two-dimensional, with long axis in the east-west direction.

As the first example, compound parabolic collector
(CPC) must be reoriented periodically during the year to keep the sun within their ranges of acceptance. Collector with large acceptance angles needs less adjustment during the year.

The second example is Fresnel lens collectors with the main axis in the north-south orientation. In this configuration, the north end must be elevated so as to tilt the collector. The yearly optical efficiencies are shown in table (8)

Table (8).relative yearly optical efficiencies of Fresnel lens systems [4].

\begin{tabular}{|c|c|}
\hline Lens configuration & Relative efficiency \\
\hline Two-axis tracking(N/S) & $1+2$ \\
\hline Seasonally adjusted(N/S) & 0.95 \\
\hline Fixed tilt(N/S) & 0.7 \\
\hline \multicolumn{2}{|c|}{ One axis tracking } \\
\hline One axis tracking $(\mathrm{E} / \mathrm{W})$ & 0.6 \\
\hline Seasonally adjusted(E/W) & 0.5 \\
\hline
\end{tabular}




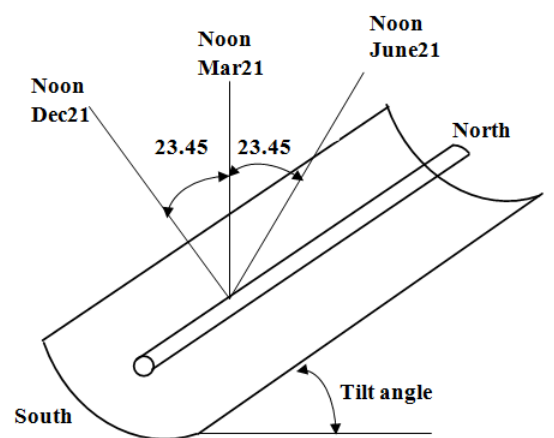

Figure (18).PTC with long axis in the $N-S$

direction [4].

The third example is parabolic trough collector (PTC). It can be mounted in several different ways. The most common method is to mount the collector horizontally with the long axis in the east-west direction as shown in figure(18).it can also be mounted with the long axis with the north-south direction. The tilt angle is a very important parameter for north-south direction. East-west orientation collects roughly equal amount of on clear days for all days of the year. While, north-south orientation collects very strongly in the summer and very weekly in the winter, as indicated in figure(19)

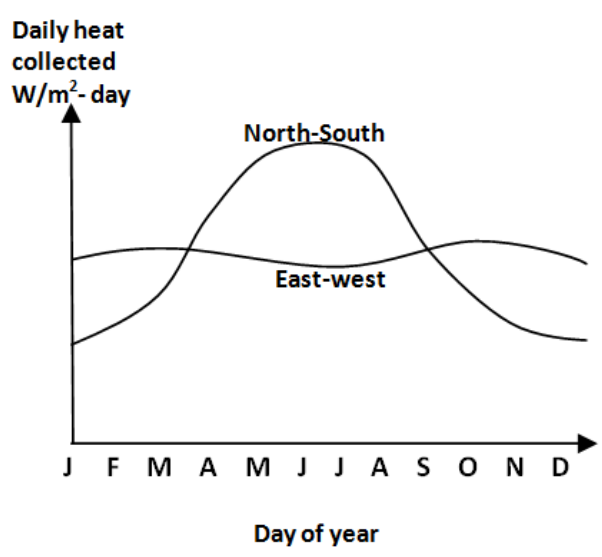

Figure (19).Estimated heat collection of a horizontal PTC per day per unit area of aperture on clear days [4].

\subsection{Solar Tracking Methods}

Solar tracking methods are passive, using an openloop approach or active using a closed loop [6]. Passive tracking methods employ Astronomical algorithms (AA) and compute the solar position as a function of position and time. This type of positioning is limited in precision and depends only on the precision of the algorithms, provided that electromechanic precision is acceptable. For this type of positioning, the azimuth axis vertical alignment and zenith horizontal alignment is of crucial importance to the overall tracking accuracy [6].

Active tracking methods use light sensitive electronics to see the sun and position themselves in a very dynamic way to the best position. Restrictions applying to this type of tracking are in the sensitivity of the sensors and the level of intelligence of the control system.

Active tracking methods work in the approach of brightest point in the-sky. Thus, unwanted movement of the device in cloudy conditions can be expected, leading to increased power consumption, mechanical wear. The precision range of active tracked systems is between 0.2 to several degrees, depending on the system design.

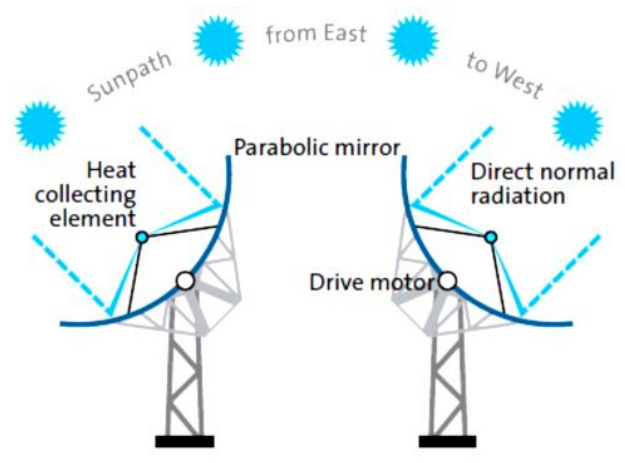

Figure (20). Daily tracking of PT collectors [60,61].

\section{Economics $[1-10,3,60,61]$}

\subsection{The current cost of CSP [3]}

According to the International Energy Agency (IEA, 2010) and National renewable energy Laboratory (NREL), costs of CSP plants can be grouped into three categories:

- Investment costs (also called capital cost or CAPEX),

- Operation and maintenance costs (O\&M) which is so called OPEX.

- Financing costs.

The cost of PT and ST plants with thermal energy storage is generally between $\$ 5000$ and $\$ 10500 / \mathrm{kW}$ as listed in Table (9). The current levelized cost of electricity (LCOE) from CSP technology are listed in table(10). The other cost data are represented in figures (21.a, b, c, d, e and f). 
Table (9). Capital Costs and key parameters of PT and ST Plant [3, 62-63].

\begin{tabular}{|c|c|c|c|c|c|c|}
\hline & Source & Heat transfer fluid & $\begin{array}{l}\text { Solar } \\
\text { multiple }\end{array}$ & Storage(hours) & $\begin{array}{l}\text { Capacity factor } \\
(\%)\end{array}$ & $\begin{array}{l}\text { Cost }(2010 \\
\text { USD/kWe })\end{array}$ \\
\hline \multirow{8}{*}{$\begin{array}{l}\text { Parabolic } \\
\text { trough }\end{array}$} & Turchi, 2010a & Synthetic oil & 1.3 & 0 & 26 & 4600 \\
\hline & Hinkley, 2011 & Synthetic oil & 1.3 & 0 & 23 & 7144 \\
\hline & Turchi, 2010a & Synthetic oil & 2 & 6 & 41 & 8000 \\
\hline & Turchi, 2010b & Synthetic oil & 2 & 6.3 & $47-48$ & $8950-9810$ \\
\hline & Hinkley, 2011 & Synthetic oil & 2 & 6 & 43 & 7732 \\
\hline & Fichtner, 2010 & Molten salt & 2.8 & 4.5 & 50.7 & 3800 \\
\hline & & & 2.5 & 9 & 56 & 7550 \\
\hline & & & 3 & 13.4 & 67 & 9140 \\
\hline \multirow{7}{*}{ Solar tower } & $\begin{array}{l}\text { Ernst and Young/ } \\
\text { Fraunhofer, } 2011\end{array}$ & Molten salt & & 7.5 & & 7280 \\
\hline & Turchi, 2010 & Molten salt & 1.8 & 6 & 43 & 6300 \\
\hline & Kolb, 2011 & Molten salt & 2.1 & 9 & 48 & 7427 \\
\hline & Hinkley, 2010 & Molten salt & 1.8 & 6 & 41 & 7463 \\
\hline & Fichtner, 2010 & Molten salt & 2 & 9 & 54 & 7720 \\
\hline & & & 3 & 12 & 68 & 9060 \\
\hline & & & 3 & 15 & 79 & 10520 \\
\hline
\end{tabular}

Table(10). Low and high LCOE figures for PTC \& ST [3,62-63]

\begin{tabular}{|c|c|c|c|c|c|}
\hline \multirow[b]{2}{*}{ CSP type and source } & \multicolumn{2}{|c|}{2011} & \multicolumn{2}{|c|}{2012} & \multirow[b]{2}{*}{ Notes } \\
\hline & Low estimate & High estimate & $\begin{array}{l}\text { Low } \\
\text { estimate }\end{array}$ & $\begin{array}{l}\text { High } \\
\text { estimate }\end{array}$ & \\
\hline \multicolumn{6}{|c|}{$(\$ / \mathrm{kWh})$} \\
\hline \multicolumn{6}{|l|}{ Parabolic trough } \\
\hline IEA, 2010 & 0.20 & 0.295 & 0.10 & 0.14 & Large plant, $10 \%$ discount rate \\
\hline Fichtner, 2010 & 0.22 & 0.24 & & & $\begin{array}{l}\text { Proposed plant in South Africa. 8\% discount } \\
\text { rate. Lower end is for } 100 \text { MW plant with } \\
\text { storage }\end{array}$ \\
\hline & 0.33 & 0.36 & & & $\begin{array}{l}\text { LCOE for India, lower value is for wet-cooled } \\
\text { and higher value for dry-cooled }\end{array}$ \\
\hline & 0.22 & 0.23 & & & $\begin{array}{l}\text { LCOE for Morocco, lower value is for wet- } \\
\text { cooled } \\
\text { and higher value for dry-cooled }\end{array}$ \\
\hline $\begin{array}{l}\text { Based on Kutscher, } \\
\text { et al., } 2010\end{array}$ & 0.22 & & 0.10 & 0.11 & $\begin{array}{l}\text { Data for the United States, adjusted to exclude } \\
\text { impact of tax credits }\end{array}$ \\
\hline Hinkley, et al., 2011 & 0.21 & & 0.13 & & $\begin{array}{l}\text { Data for a } 100 \mathrm{MW} \text { plant in Queensland, } \\
\text { Australia. } 7 \% \text { discount rate. }\end{array}$ \\
\hline \multicolumn{6}{|l|}{ Solar Tower } \\
\hline \multirow[t]{3}{*}{ Fichtner, 2010} & 0.185 & 0.202 & & & $\begin{array}{l}\text { Proposed plant in South Africa. } 8 \% \text { discount } \\
\text { rate. Lower end is for } 100 \mathrm{MW} \text { plant with } \\
\text { storage }\end{array}$ \\
\hline & 0.27 & 0.28 & & & $\begin{array}{l}\text { LCOE for India, lower value is for wet-cooled } \\
\text { and higher value for dry-cooled }\end{array}$ \\
\hline & 0.22 & 0.23 & & & $\begin{array}{l}\text { LCOE for Morocco, lower value is for wet- } \\
\text { cooled and higher value for dry-cooled }\end{array}$ \\
\hline Kolb, et al., 2010 & 0.16 & 0.17 & 0.08 & 0.09 & $\begin{array}{l}\text { Data for the United States, adjusted to exclude } \\
\text { impact of tax credits }\end{array}$ \\
\hline Hinkley, et al., 2011 & 0.21 & & 0.16 & & $\begin{array}{l}\text { Data for a } 100 \mathrm{MW} \text { plant in Queensland, } \\
\text { Australia. } 7 \% \text { discount rate. }\end{array}$ \\
\hline \multicolumn{6}{|c|}{ Parabolic trough and solar towers } \\
\hline A.T. Kearney, 2010 & 0.23 & 0.32 & 0.13 & 0.16 & \\
\hline
\end{tabular}




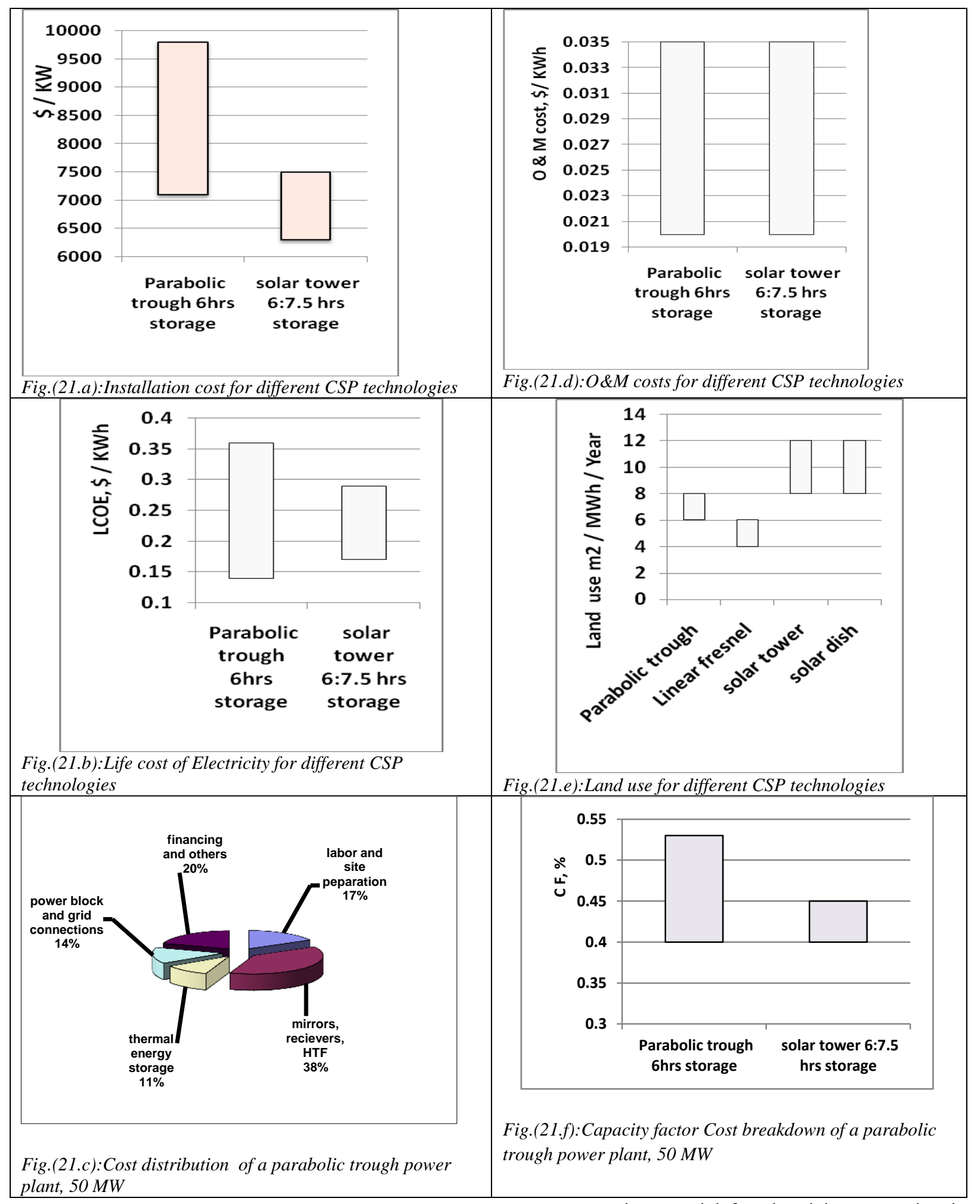

\section{Conclusion}

From the present study, it is concluded that:

- MENA region has a great potential for renewable energy and CSP is the future economic potential for electricity generation in MENA region.

- Governments of Developing countries have to realize, encourage and apply incentives for deployment of CSP projects. This can be 
achieved through investment and researches.

- To produce power from solar heat energy, high temperature is needed, so concentration of incoming solar radiation is necessary using solar concentrators. Radiation needs to be focused onto a small target. So, concentrator optics and orientation needs to be accurate.

- Only beam radiation can be concentrated. Solar tracking is necessary (small $\cos \theta)$.

- Concentration ratio (C) $=60-100$ can give up to $400 \mathrm{C}$, while $\mathrm{C} \geq 200$ can give temperature of 600-1000 ${ }^{0} \mathrm{C}$.

- Concentration ratio is $25: 100,70: 80,300: 1000$, 1000-3000 for PT, ST, LF and Dish Stirling respectively.

- For PT, the ideal solar concentration ratio, $\mathrm{C}_{\text {ideal }, 2 \mathrm{D}}=\frac{1}{\sin \theta}$

Where $2 \mathrm{D}$ denotes to two dimensional (i.e PT collector).

- . Taking sun's angular width $=32^{\prime}(0.5333$ $\operatorname{deg} / 2=\theta$.). Then $\mathrm{C}_{\mathrm{idea}, 2 \mathrm{D}}=214$. If higher $\mathrm{C}_{\mathrm{ideal}, 2 \mathrm{D}}$ is required, a secondary mirror may be necessary.

- Yearly efficiency is 15: $25 \%$ for power generation from CSP power plants.

- Using heat storage, 5:7 hrs more operational time per day can be achieved.

- Land area requirement: based on generation weighted are 4:6, 6:8, 8:12, 8:12 $\mathrm{m}^{2} / \mathrm{MWh} /$ year for LF, PT, ST and Dish Stirling respectively.

- CSP plants are capital intensive, but have zero fuel costs. PT plant without TES has capital costs as low as $\$ 4600 / \mathrm{KW}$, but low capacity factors of 0.2: 0.25 . Adding of 6 hours of TES increases capital costs to $\$ 7100$ : $9800 / \mathrm{kW}$, but the capacity factors will be doubled.

- For ST plants, capital costs are \$6300, $10500 / \mathrm{kW}$ when TES is 6 and $15 \mathrm{hrs}$ respectively. The corresponding capacity factors are 0.4 and 0.8 respectively.

- For CSP plants, O\&M costs are $\$ 0.02: 0.035 / \mathrm{kWh}$, which is relatively considered high.

- The LCOE is mainly depending on capital costs and the local solar resource. For instance, for a given CSP plant, the LCOE will be around one quarter lower for a DNI of $2700 \mathrm{KWh} / \mathrm{m}^{2} /$ year than for a site with $2100 \mathrm{kWh} / \mathrm{m}^{2} /$ year.

- For CSP plants, the LCOE is currently high.
Today, the LCOE is $\$ 0.2: 0.36 / \mathrm{kWh}$ and $\$ 0.17: 0.29 \mathrm{kWh}$ for PT and ST plants respectively (at $10 \%$ cost of capitals). However for areas with excellent solar resources [MENA regions), it could be as low as $\$ 0.14: 0.18 \$ / \mathrm{kWh}$.

- Potential for Cost reduction is possible. For instance, for $1.9 \mathrm{GW}$ of installed capacity, by year 2015, the LCOE will decline to \$0.18:0.32/kWh and \$0.15: $0.24 / \mathrm{kWh}$ for PT and ST plants respectively.

- ST plants might become the choice in future. Because it can achieve a very high temperatures with manageable losses using molten salt as a heat transfer fluid.

- Typical capacity is 10:300, 10:200, 10:200 and 0.01:0.025 MW for PT, ST, LF and Dish Stirling respectively.

- Operating temperature is 350:550, 250:565, 390, 550:750 ${ }^{0} \mathrm{C}$ for PT, ST, LF and Dish Stirling respectively.

- Plant peak efficiency is $14: 20,23: 35,18$ and $30 \%$ for PT, ST, LF and Dish Stirling respectively.

- Annual solar to electric efficiency (net) is $11: 16 \%, 7: 20 \%, 13 \%, 12: 25 \%$ for PT, ST, LF and Dish Stirling respectively.

- Annual capacity factor is 29:43(7h TES), 55(10h TES), 22:24, 25:28\% for PT, ST, LF and Dish Stirling respectively.

- Collector concentration is 70$80,>1000,>60,>1300$ suns for PT, ST, LF and Dish Stirling respectively.

- Steam conditions ( $\mathrm{T}$ in $\mathrm{C}^{\mathrm{o}}$ and $\mathrm{P}$ in bar) are $\left(380: 540{ }^{\circ} \mathrm{C}\right) / 100$ bar, $540 / 100$ to $160: 260 / 50$, N/A for PT, ST, LF and Dish Stirling respectively.

- Water requirement in $\mathrm{m}^{3} / \mathrm{MW}$ of plant capacity is given below

\begin{tabular}{|c|c|c|c|}
\hline $\begin{array}{l}\text { PT } \\
\text { plant }\end{array}$ & ST plant & LF plant & $\begin{array}{l}\text { Dish- } \\
\text { Stirling }\end{array}$ \\
\hline $\begin{array}{l}3 \text { (wet } \\
\text { cooling) } \\
0.3 \text { (dry } \\
\text { cooling) }\end{array}$ & $\begin{array}{l}2-3 \text { (wet } \\
\text { cooling) } \\
0.25 \text { (dry } \\
\text { cooling) }\end{array}$ & $\begin{array}{l}3 \text { (wet } \\
\text { cooling) } \\
0.2 \text { (dry } \\
\text { cooling) }\end{array}$ & $\begin{array}{l}0.05-0.1 \\
\text { (mirror } \\
\text { washing) }\end{array}$ \\
\hline
\end{tabular}

- Labor represents $17 \%$ of the project cost and is an area where local resources can help to reduce costs in developing countries. Based on experience with Andasol 1, the site improvements, installation of the plant components and completion of the plant will require manpower of around 500 people.

- The most promising components that could be locally manufactured or provided by developing 
countries are support structures, mirrors and receivers.

- Effect of orientation for 1-axis tracking:

- The performance of concentrated solar collectors (CSCs) depends on their orientation. Comparing north-south against east-west oriented collectors; it will have higher output over the year (roughly 5: 8\%). While east-west oriented collectors have longer operating hours and therefore higher output in winter times.

\begin{tabular}{ll} 
Nomenclature & \\
CAPEX & Capital Expenditure \\
DNI & Direct normal insolation, $\mathrm{kwh} / \mathrm{m}^{2}$ \\
HVAC & Heating, ventilating and air conditioning \\
PT & Parabolic trough \\
S T & Solar tower \\
LCOE & Levelized cost of energy, $\$ \mathrm{kWhe}$ \\
CSP & Concentrated solar power \\
MENA & Middle east and north Africa \\
MWht & Megawatt hour thermal power \\
MWhe & Megawatt hour electric power \\
TES & Thermal energy storage \\
Subscripts & \\
\multicolumn{1}{c}{ e } & electric \\
t & thermal \\
Greek Symbols \\
$\eta$ & Efficiency \\
\end{tabular}

\section{References}

[1] Dascomb,J 2009 "Low-cost concentrating solar collector for steam generation" MSc thesis, Florida state university.

[2] International Renewable energy Agency(IRENA), 2012"CSP cost analysis"

[3] Donal Rapp, 1981 "Solar energy book: Solar collectors".

[4] Yidnekachew Messele, 2012" Thermal Analysis, Design and Experimental Investigation of Parabolic Trough Solar Collector "MSc thesis, Addis Ababa University.

[5] Incropera \& DeWitt, 1996"Heat transfer"

[6] Radu D. Rugescu, 2010" Solar Energy " WWW.intechweb.org.

[7] Hammons,T.J., 2009 "Renewable Energy " WWW.intechweb.org

[8] Elisha B. Babatunde, 2012" Solar radiation" www.intechopen.com.

[9] Intech book, 2012"Renewable Energy" Intecweb.org.

[10] Trieb, F., 2005"Concentrating solar power for the Mediterranean region" German Aero Space center.

[11] Solar thermal power -the basics, European Solar Thermal Industry Association, 2005.

[12] Thomas Stoffel, Daryl Myers, David Renne, Stephen Wilcox, Ray George and Craig Turchi,2010'Introducing NREL'S best practices handbook for collection and use of solar resource data for CSP" NREL/TP-550-47465.

[13] 13]CSP today, 2013 "CSP projects \& prospects guide USA 2013” WWW.csptoday.com/USA
[14] CSP today,2008"An overview of CSP in Europe andMENA"MENASOL2013,WWW.CSPtoday.com/m ena

[15] http://www.iea.org/publications/freepublications/publi cation/csp_roadmap.pdf

[16] Arif Hepbasli, Zeyad Alsuhaibani, 2011" A key review on present status and future directions of solar energy studies and applications in Saudi Arabia" Renewable and Sustainable Energy Reviews 15 (2011) 5021- 5050.

[17] European Academies Science Advisory Council(EASAC), 2011 "Concentrating solar power: its potential contribution to a sustainable energy future" www.easac.eu.

[18] M.C. Barbato, Ph. Haueter, R. Bader, A. Steinfeld, A. Pedretti, 2008" Solar innovative solar collectors for efficient and cost-effective solar thermal power generation" Umwelt, Verkehr, Energie und Kommunikation UVEK.

[19] R. Bose, D.J. Farrell, C. Pardo-Sanchez, M. Pravettoni,M. Mazzer,A.J. Chatten, and K.W.J. Barnham, "luminescent solar concentrators: cylindrical design”rahul.bose@imperial.ac.uk.

[20] Tongxin Wang, Jun Zhang, Wei Ma, Yanhua Luo, Lijuan Wang, Zhijia Hu,2011" Luminescent solar concentrator employing rare earth complex with zero self-absorption loss" Solar Energy 85 (2011) 25712579.

[21] Ayadi, 2011"Solar cooling systems, utilizing concentrated solar collectors, design, experimental evaluation \& optimization " $\mathrm{PhD}$ thesis Politeccico DI, MILANO.

[22] Zurich, E, 2011" Optical and thermal analysis of an air-based solar trough concentrating system " $\mathrm{PhD}$ thesis, ETH ZURICH.

[23] NREL Concentrating Power Research www.nrel.gov/csp

[24] David C. Miller, Sarah R. Kurtz,2011 "Durability of Fresnel lenses: A review specific to the concentrating photovoltaic application" Solar Energy Materials \& Solar Cells 95 (2011) 2037-2068.

[25] Nadejda Komendantova, Anthony Patt, Keith Williges, 2011" Solar power investment in North Africa: Reducing perceived risks" Renewable and Sustainable Energy Reviews 15 (2011) 4829- 4835.

[26] Newton,C.C., 2007" A concentrated solar thermal energy system" the Florida State University FAMUFSU College of engineering.

[27] Valenzuela,J.M., 2011" Performance of A 50 MW concentrating Solar Power Plant "Politecnico DI BARI.

[28] Sargent \& Lundy LLC Consulting Group Chicago, Illinois,2003" Assessment of Parabolic Trough and Power Tower Solar Technology Cost and Performance Forecasts" NREL/SR-550-34440.

[29] Abdulrahim A. T, Diso I. S.,and Abdulraheem A. S, 2012 "Design analysis of solar bi-focal collectors" Journal of Mechanical Engineering Research Vol. 4(4), pp. 136-141, April 2012.

[30] Daniel Horst,2012" Performance Simulation For Parabolic Trough Concentrating Solar Power Plants 
And Export Scenario Analysis For North Africa "MSc thesis, FACULTY OF ENGINEERING, CAIRO UNIVERSITY GIZA, EGYPT.

[31] Andrew James Marston,2010" Geometric Optimization of Solar Concentrating Collectors using Quasi-Monte Carlo Simulation "MSc ,University of Waterloo, Waterloo, Ontario, Canada, 2010.

[32] Ahmad Khaled, "TECHNICAL AND ECONOMIC PERFORMANCE OF PARABOLIC TROUGH IN JORDAN" M.Sc. thesis, University of Kassel, Germany., Faculty of Engineering at Cairo University, Egypt.

[33] Thermal Storage and Advanced Heat Transfer Fluids, NREL/FS-550-48660 • August 2010.

[34] Roman Adinberg,2011" Simulation analysis of thermal storage for concentrating solar power" Applied Thermal Engineering 31 (2011) 3588e3594.

[35] Paul Denholm and Mark Mehos,2011 "Enabling Greater Penetration of Solar Power via the Use of CSP with Thermal Energy Storage" NREL/TP-6A2052978.

[36] Zhao, C.Y. Wu, Z.G., 2011" Thermal property characterization of a low melting-temperature ternary nitrate salt mixture for thermal energy storage systems" Solar Energy Materials \& Solar Cells 95 (2011) 3341-3346.

[37] Christopher W. Robak, Theodore L. Bergman, Amir Faghri,2011" Economic evaluation of latent heat thermal energy storage using embedded thermosiphons for concentrating solar power applications" Solar Energy 85 (2011) 2461-2473.

[38] Zhiwen Ma, Greg Glatzmaier, Craig Turchi, and Mike Wagner, "THERMAL ENERGY STORAGE PERFORMANCE METRICS AND USE IN THERMAL ENERGY STORAGE DESIGN"

[39] AQUA-CSP 2007: Trieb, F., Schillings, C., Viebahn, P., Paul, C., Altowaie, H., Sufian, T., Alnaser, W., Kabariti, M., Shahin, W., Bennouna, A., Nokraschy, H., Kern, J., Knies, G., El Bassam, N., Hasairi, I., Haddouche, A., Glade, H., Aliewi, A., "Concentrating Solar Power for Seawater Desalination" German Aerospace Center (DLR), Study for the German Ministry of Environment, Nature Conversation and Nuclear Safety, Stuttgart 2007, (www.dlr.de/tt/aquacsp)

[40] Daniel Chemisana, JesúsLópez-Villada, Alberto Coronas, Joan IgnasiRosell, Chiara Lodi, 2012" Building integration of concentrating systems for solar cooling applications "Applied Thermal Engineering (2012) 1-8.

[41] Shamseen,A.M.1993" simulation study of reverse osmosis desalination system powered by combined solar and wind power plants optimization of the dimensions of wind and solar subsystems" University of Athens.

[42] Hazim Mohameed Qiblawey, Fawzi Banat" Solar thermal desalination technologies" Desalination 220 (2008) 633-644.

[43] MENA Regional Water Outlook Part II Desalination Using Renewable Energy Task 2 - Energy Requirement, 6543P07/FICHT-6971711-v4.
[44] Ummadisingu, A., Soni, M.S., 2011 "Concentrating solar power- Technology, potential and policy in India" Renewable and Sustainable Energy Reviews 15 (2011) 5169- 5175.

[45] Muhammad Tauha Ali, Hassan E.S. Fath, Peter R. Armstrong,2011" A comprehensive technoeconomical review of indirect solar desalination" Renewable and Sustainable Energy Reviews 15 (2011) 4187-4199.

[46] Regina Wilde, 2005" Case Study of a Concentrating Solar Power Plant for the Cogeneration of Water and Electricity" Diploma thesis, DLR.

[47] Concentrating Solar Power Commercial Application Study: Reducing Water Consumption of Concentrating Solar Power Electricity Generation, Report to Congress U.S. Department of Energy,2001

[48] IORDANOU, GRIGORIOS,2009" Flat-Plate Solar Collectors for Water Heating with Improved Heat Transfer for Application in Climatic Conditions of the Mediterranean Region" School of Engineering and Computing Science Durham University.

[49] MENA Regional Water Outlook,2011, Part II Desalination Using Renewable Energy Task 2 Energy Requirement, MENA@fichtner.de.

[50] X.Q. ZhaiM. Qu, Yue. Li, R.Z. Wang,2011" A review for research and new design options of solar absorption cooling systems" Renewable and Sustainable Energy Reviews 15 (2011) 4416-4423.

[51] Z.F. Li, K. Sumathy, 2000" Technology development in the solar absorption air-conditioning systems" Renewable and Sustainable Energy Reviews 4 (2000) 267-293.

[52] Patricia Palenzuela, Guillermo Zaragoza, Diego C. Alarcón-Padilla, Julián Blanco,2011" Evaluation of cooling technologies of concentrated solar power plants and their combination with desalination in the Mediterranean area" Applied Thermal Engineering xxx (2011) 1-8.

[53] Lucier RE. Apparatus for converting solar to electrical energy. US. Patent; 1979.

[54] Robert Y. Ning, 2012 "Advancing Desalination" www.intechopen.com

[55] Trieb, Moser, Fichter, DLR, Verdier, 2011 "MENA Regional Water Outlook Part II , Desalination Using Renewable Energy Task 2 - Energy Requirement, FICHTNER, DLR, www.fichtner.de

[56] Lapetrov, 2011" Solar tracking strategies" BSc Dissertation, DUNDEE university.

[57] Khademul Islam Majumder, Raied Hasan and Raquib Ahmed, 2010" Improvement Of efficiency For solar PHOTOVOLTAIC Cell Application" BRAC University, Dhaka, Bangladesh.

[58] Justin Matthew Hallas,2011" Automated MicroTracking Planar Solar Concentrators "MSc thesis, UNIVERSITY OF CALIFORNIA, SAN DIEGO.

[59] L A Petrov,2011" Solar tracking strategies "BSc Dissertation, DUNDEE university.

[60] C. Turchi,2010"Parabolic Trough Reference Plant for Cost Modeling with the Solar Advisor Model (SAM)" Technical Report NREL/TP-550-47605July 2010.

[61] Sargent \& Lundy LLC Consulting Group Chicago, 
Illinois,2003" Assessment of Parabolic Trough and Power Tower Solar Technology Cost and Performance Forecasts" NREL/SR-550-34440.

[62] Advanced Reflector and Absorber Materials, NREL

[63] David Barlev, RuxandraVidu, Pieter Stroeve, 2011" Innovation in concentrated solar power" Solar Energy Materials \& Solar Cells 95 (2011) 2703-2725.

[64] Angela, M., 2006 "Simulation and Performance Evaluation of Parabolic Trough Solar Power Plants" MSc thesis, university of wisconsin-madison.

[65] R.H. French, J.M. Rodri'guez-Parada, M.K. Yang, R.A. Derryberry, N.T. Pfeiffenberger, 2011" Optical properties of polymeric materials for concentrator photovoltaic systems" Solar Energy Materials \& Solar Cells 95 (2011) 2077-2086.

[66] John Chung-Ling Chien, Noam Lior, 2011" Concentrating solar thermal power as a viable alternative in China's electricity supply" Energy Policy 39 (2011) 7622-7636.

[67] Javier Munoz, Alberto Abnades, 2011" Analysis of internal helically finned tubes for parabolic trough design by CFD tools" Applied Energy 88 (2011) 4139-4149.

[68] Gui-Long Dai, Xin-Lin Xia, Chuang Sun, Hao-Chun Zhang,2011" Numerical investigation of the solar concentrating characteristics of $3 \mathrm{D} \mathrm{CPC}$ and $\mathrm{CPC}$ DC" Solar Energy 85 (2011) 2833-2842.

[69] Aqeel Ahmed Bazmi, GholamrezaZahedi,2011" Sustainable energy systems: Role of optimization modeling techniques in power generation and supply-A review" Renewable and Sustainable Energy Reviews 15 (2011) 3480-3500.

[70] Modeling and Analysis of CSP Systems, National Renewable Energy Laboratory, NREL/FS-550-48661 - August 2010.
[71] Roman Badr, 2011" Optical and thermal analysis Of an air-Based Solar Trough Concentrating System "PhD thesis, DISS. ETH NO. 19772.

[72] Dustin F. Howard, 2010" Modeling Concentrated Dish-Stirling Solar Power Plants "MSc thesis, Georgia Institute of Technology.

[73] Newtonian off-axis aberrations, http://www.telescopeoptics.net/newtonian_off_axis_aberrations.htm.

[74] Michael J. Wagner, $201 \overline{2}$ "Results and Comparison from the SAM Linear Fresnel Technology Performance Model" World Renewable Energy Forum Denver, Colorado May 13-17, 2012.

[75] NREL Solar Data and Tools.

[76] Intech book,2012 "Modeling and Optimization of renewable energy systems"Intechopen.com.

[77] Intech book, 2012"Numerical Modeling" Intechopen.com

[78] Yidnekachew Messele, 2012" Thermal Analysis, Design and Experimental Investigation of Parabolic Trough Solar Collector "MSc thesis, Addis Ababa University.

[79] solar thermal power system, chapter ten: www.powersolar.com

[80] Expert group meeting-Emerging Renewable Energy technologies for India, 2010.

[81] Adesten,M, 2002"design and performance of non tracking concentrators " $\mathrm{PhD}$ thesis, Uppsala university.

[82] Solar thermal power system, chapter eight: www.powersolar.com

[83] A bdulkarim Mayere, BEng, PgDip, 2011" Solar Powered Desalination" $\mathrm{PhD}$ thesis, University of Nottingham 